\title{
PENINGKATAN KINERJA GURU DALAM PEMBELAJARAN DI KELAS MELALUI SUPERVISI EDUKATIF KOLABORATIF SECARA PERIODIK DI SD NEGERI LEUWIGAJAH 2
}

\author{
Kusmiati \\ SD Negeri Leuwigajah 2, Cimahi, Jawa Barat, Indonesia \\ itakusmiati19@gmail.com
}

\begin{abstract}
ABSTRAK
Penelitian ini dilatarbelakangi rendahnya kesadaran guru untuk belajar, kurangnya kesempatan guru mengikuti pelatihan, kurang efektifnya KKG dan supervise Pendidikan yang bertujuan memperbaiki proses pembelajaran cenderung menitik beratkan pada administrasi di SD Negeri Leuwigajah 2. Penelitian ini bertujuan untuk memperbaiki kinerja dan wawasan guru dalam pembelajaran di SD Negeri Leuwigajah 2 Kecamatan Cimahi Selatan Kota Cimahi serta untuk mengetahui ada tidaknya manfaat Supervisi Edukatif Kolaboratif secara Periodik terhadap mutu kinerja dan wawasan guru. Hasil Penelitian menunjukkan kemajuan dan peningkatan yang signifikan pada setiap siklusnya. Dengan Supervisi Edukatif Kolaboratif Secara Periodik mampu meningkatkan kinerja dan wawasan guru. Dari hasil penelitian ini, ditemukan beberapa hipotesis yang kebenarannya perlu dibuktikan lebih lanjut, bahwa dengan adanya Supervisi Edukatif Kolaboratif Secara Periodik dapat meningkatkan prestasi belajar siswa di SD Negeri Leuwigajah 2 Kecamatan Cimahi Selatan Kota Cimahi. Penulis berharap untuk tahun-tahun berikutnya Supervisi Edukatif Kolaboratif Secara Periodik dapat dilaksanakan sebaik-baiknya. Hal ini dikarenakan dengan pelaksanaan Supervisi Edukatif Kolaboratif Secara Periodik yang baik, ternyata dapat berpengaruh terhadap prestasi belajar siswa.
\end{abstract}

Kata kunci: Meningkatkan Kinerja Guru, Supervisi Edukatif Kolaboratif

\begin{abstract}
This research is motivated by the low awareness of teachers to learn, the lack of opportunities for teachers to attend training, the ineffectiveness of the KKG and supervision. Education aimed at improving the learning process tends to focus on administration at Leuwigajah State Elementary School. Negeri Leuwigajah 2, Cimahi Selatan District, Cimahi City and to find out whether there are benefits of Periodic Collaborative Educative Supervision on teacher quality and insight. Research results show progress and significant improvement in each cycle. By Periodic Collaborative Educative Supervision can improve teacher performance and insight. From the results of this study, it was found several hypotheses whose truths need to be further proven, that with the existence of Periodic Collaborative Educative Supervision can improve student learning achievement in Leuwigajah 2 Elementary School in South Cimahi District, Cimahi City. The author hopes that for the following years Periodic Collaborative Educative Supervision can be carried out as well as possible. This is because with the implementation of Periodic Collaborative Educating which is good, it turns out it can have an effect on student learning achievement.
\end{abstract}

Keywords: Improving Teacher Performance, Collaborative Educative Supervision

\section{PENDAHULUAN}

Berdasarkan diskusi yang dilakukan pada 10 orang guru di SD Negeri Leuwigajah 2, kinerja dan wawasan guru belum memuaskan. Hal tersebut terbukti dari hasil Penilaian Kinerja Guru (PKG), dari
10 orang guru, 6 guru $(60 \%)$ yang belum memahami cara menyusun rencana pembelajaran, melaksanakan pembelajaran yang aktif, kreatif, efektif dan menyenangkan, dan menilai prestasi belajar siswa dan 4 guru (40\%) sudah 
memahaminya. Hal ini diakibatkan oleh: (1). Rendahnya kesadaran guru untuk belajar, (2). Kurangnya kesempatan guru untuk mengikuti pelatihan baik secara regional maupun nasional, (3). Kurang efektifnya KKG, (4) Supervisi Pendidikan yang bertujuan memperbaiki proses pembelajaran cenderung menitik beratkan pada aspek administrasi.

Untuk menangani masalah tersebut, salah satu solusi yang dapat dilakukan adalah dengan menggunakan metode Supervisi Edukatif Kolaboratif yang difokuskan pasa supervisi Edukatif saja. Dengan demikian, diharapkan keterampilan guru bertambah dan dapat meningkatkan kinerja dan wawasan guru dengan memuaskan.

Supervisi merupakan salah satu tugas kepala sekolah yang bertujuan untuk memperbaiki dan meningkatkan pengelolaan dari aspek yang di supervise dan orang yang melakukan supervisi. Supervisi edukatif merupakan supervisi yang diarahkan pada kurikulum, pembelajaran proses belajar mengajar, pelaksanaan bimbingan dan konseling. Menurut Ditjen Dikmenum (1994:15) pelaksanaan supervis tersebut dapat dilakukan dengan cara: (1). Wawancara, (2). Observasi. Jika supervisi dilakukan pengawas kepada kepala sekolah, pengawas bisa melaksanakan wawancara dengan kepala sekolah yang berkaitan dengan kelengkapan dokumen kurikulum. Selain wawancara, pengawas dan atau kepala sekolah dapat melaksanakan observasi kepada guru dalam proses belajar mengajar atau dalam kegiatan bimbingan konseling. Menurut Ditjen Dikmenun (1994:16) observasi tersebut bisa berupa:

1. Observasi kegiatan belajar mengajar, meliputi:

a. Persiapan mengajar,

Populasi pada penelitian ini adalah seluruh mahasiswa PGSD semester 4 kelas regular dan kelas non reguler dengan jumlah 392
b. Pelaksanaan satuan pengajaran didalam kelas, dan
c. Pelaksanaan penilaian.

2. Observasi kegiatan bimbingan konseling, meliputi:
a. Program kegiatan bimbingan konseling di sekolah,
b. Pelaksanaan bimbingan konseling di sekolah,
c. Kelengkapan administrasi/perlengkapan bimbingan konseling
d. Penilaian dan laporan.

Berdasarkan uraian di atas, berikut merupakan pertanyaan penelitian yang hendak dijawab.

1. Apakah melalui Supervisi Edukatif Kolaboratif dapat meningkatkan kinerja guru dalam pembelajaran di kelas?

2. Bagaimana pengaruh terhadap guru dalam pelaksanaan Supervisi Edukatif Kolaboratif?

\section{METODE}

Penelitian dilaksanakan di SD Negeri Leuwigajah 2 Kota Cimahi pada tahun pelajaran 2018-2019 sejak Juli hingga Desember 2018. Subjek yang terlibat dalam penelitian adalah guru-guru SD yang terdiri dari 10 orang. Metode yang dipergunakan adalah metode deskriptif analitik untuk mengetahui hasil kinerja guru sebelum (prasiklus) dan setelah penilaian (siklus I dan siklus II) kinerja dengan menggunakan metode Supervisi Edukatif Kolaboratf. Dengan demikian, data diperoleh dengan menggunakan wawancara dan lembar obserbasi. Setelah data diperoleh, data akan diolah untuk memperoleh angka persentase. Sementara data yang diperoleh dari lembar obsevasi digunakan sebagai data pendukung dalam analisis dampak penggunaan metode supervisi edukatif kolaboratif.

\section{HASIL DAN PEMBAHASAN \\ Hasil}

Data yang dijaring dalam penelitian ini, yaitu data Penilaian Kinerja Guru. Namun 
sebelum dilakukan penelitian tindakan sekolah, peneliti melakukan observasi awal tentang kinerja guru di sekolah. Penilaian Kinerja Guru (PKG) dijadikan acuan untuk mengetahui hasil kinerja guru setelah digunakan model supervisi edukatif kolaboratif secara periodik. Berdasarkan pemantauan selama persiapan pelaksaaan dan tindak lanjut penelitian tindakan ini diperoleh berbagai data, baik dari guru yang sedang melaksanakan proses belajar mengajar maupun supervisor yang sedang melakukan supervisinya. Hasil siklus pertama dapat dinilai pada tabel berikut:

Tabel 1. Hasil Penentuan Perencanaan Siklus I

\begin{tabular}{|c|c|c|c|c|}
\hline NO & Indikator & $\begin{array}{c}\text { Jumlah } \\
\text { Guru }\end{array}$ & $\begin{array}{c}\text { Jumlah Guru } \\
\text { berhasil } \\
\text { (skor }>75)\end{array}$ & $\begin{array}{c}\% \\
\text { keberhasilan }\end{array}$ \\
\hline 1 & $\begin{array}{ll}\text { Mendiskripsikan } & \text { tujuan } \\
\text { pembelajaran } & \end{array}$ & 10 & 9 & 90 \\
\hline 2 & $\begin{array}{l}\text { Menentukan materi sesuai dengan } \\
\text { materi }\end{array}$ & 10 & 9 & 90 \\
\hline 3 & $\begin{array}{l}\text { Mengorganisasikan materi } \\
\text { berdasarkan urutan atau kelompok }\end{array}$ & 10 & 7 & 70 \\
\hline 4 & Mengalokasikan waktu & 10 & 10 & 100 \\
\hline 5 & Menentukan metode pembelajaran & 10 & 6 & 60 \\
\hline 6 & Merancang prosedur perencanaan & 10 & 7 & 70 \\
\hline 7 & Menentukan media pembelajaran & 10 & 7 & 70 \\
\hline 8 & $\begin{array}{l}\text { Menentukan sumber yang sesuai } \\
\text { berupa modul, buku komputer dan } \\
\text { sejenisnya }\end{array}$ & 10 & 9 & 90 \\
\hline 9 & $\begin{array}{l}\text { Menentukan teknis penilaian yang } \\
\text { sesuai }\end{array}$ & 10 & 4 & 40 \\
\hline \multicolumn{2}{|r|}{ Jumlah } & 10 & 68 & 76 \\
\hline
\end{tabular}

Berdasarkan tabel I dapat diketahui bahwa dalam penentuan perencanaan belajar guru memperoleh skor 68 yang mana dikatakan belum berhasil karena skor kurang dari $75 \%$ dengan jumlah guru berhasil semua dalam indikator mengalokasikan waktu dan dalam indikator menentukan metode pembelajaran hanya 6 guru yang dapat melaksanakannya.

Tabel 2. Hasil melaksanakan Pembelajaran Siklus I

\begin{tabular}{clccc}
\hline NO & \multicolumn{1}{c}{ Indikator } & $\begin{array}{c}\text { Jumlah } \\
\text { Guru }\end{array}$ & $\begin{array}{c}\text { Jumlah Guru } \\
\text { berhasil } \\
\text { (skor>75) }\end{array}$ & $\begin{array}{c}\text { \% } \\
\text { keberhasilan }\end{array}$ \\
\hline $\mathbf{1}$ & $\begin{array}{l}\text { Membuka pelajaran dengan metode } \\
\text { yang tepat }\end{array}$ & 10 & 8 & 80 \\
$\mathbf{2}$ & $\begin{array}{l}\text { Menyajikan materi pelajaran secara } \\
\text { sistematik }\end{array}$ & 10 & 6 & 60 \\
$\mathbf{3}$ & $\begin{array}{l}\text { Menerapkan metode dan prosedur } \\
\text { pembelajaran yang telah ditentukan }\end{array}$ & 10 & 6 & 60 \\
\hline
\end{tabular}




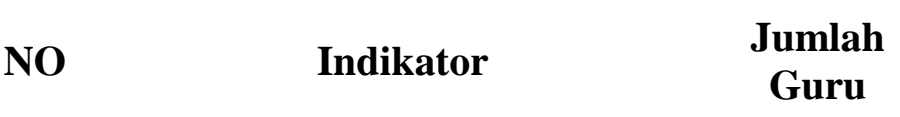

\section{Jumlah Guru berhasil (skor>75)}

$\%$

keberhasilan

\begin{tabular}{llccc}
$\mathbf{4}$ & Mengatur kegiatan siswa di kelas & 10 & 9 & 90 \\
$\mathbf{5}$ & Menentukan media pembelajaran & 10 & 5 & 50 \\
$\mathbf{6}$ & Menggunakan sumber belajar & 10 & 10 & 100 \\
$\mathbf{7}$ & $\begin{array}{l}\text { Memotivasi siswa dengan cara } \\
\text { positif }\end{array}$ & 10 & 9 & 90 \\
$\mathbf{8}$ & $\begin{array}{l}\text { Melakukan interaksi dengan siswa } \\
\text { menggunakan Bahasa yang }\end{array}$ & 10 & 9 & 90 \\
$\quad \begin{array}{l}\text { komunikatif } \\
\mathbf{9}\end{array}$ & 10 & 5 & 50 \\
$\quad \begin{array}{l}\text { Memberikan pertanyaan umpan } \\
\text { balik }\end{array}$ & 10 & 6 & 60 \\
$\mathbf{1 1}$ & $\begin{array}{l}\text { Menyimpulkan pembelajaran } \\
\quad \text { Jumlah }\end{array}$ & 10 & 5 & 50 \\
$\quad$ & 10 & 68 & 76 \\
\hline
\end{tabular}

Berdasarkan tabel 2 dapat diketahui bahwa dalam melaksanakan pembelajaran guru memperoleh skor 68 yang mana dikatakan belum berhasil karena skor kurang dari $75 \%$ dengan jumlah guru berhasil semua dalam indikator menggunakan sumber belajar dan dalam indikator menentukan media pembelajaran, memberikan pertanyaan umpan balik dan menggunakan waktu secara efektif hanya 5 guru yang dapat melaksanakannya.

Tabel 3. Hasil Menilai Prestasi Belajar Siklus I

\begin{tabular}{|c|c|c|c|c|}
\hline NO & Indikator & $\begin{array}{c}\text { Jumlah } \\
\text { Guru }\end{array}$ & $\begin{array}{c}\text { Jumlah } \\
\text { Guru } \\
\text { berhasil } \\
\text { (skor }>75)\end{array}$ & $\begin{array}{c}\% \\
\text { keberhasilan }\end{array}$ \\
\hline 1 & Menyusun soal perangkat penilaian & 10 & 9 & 90 \\
\hline 2 & Melaksanakan penilaian & 10 & 9 & 90 \\
\hline 3 & Memeriksa jawaban/memberi skor & 10 & 7 & 70 \\
\hline 4 & Menilai hasil belajar & 10 & 10 & 100 \\
\hline 5 & Mengolah hasil belajar & 10 & 6 & 60 \\
\hline 6 & Menganalisa hasil belajar & 10 & 7 & 70 \\
\hline 7 & Menyimpulkan hasil belajar & 10 & 7 & 70 \\
\hline 8 & Menyusun laporan hasil belajar & 10 & 10 & 100 \\
\hline \multirow[t]{2}{*}{9} & $\begin{array}{l}\text { Memperbaiki soal perangkat } \\
\text { penilaian }\end{array}$ & 10 & 10 & 100 \\
\hline & Jumlah & 10 & 68 & 76 \\
\hline
\end{tabular}

Berdasarkan tabel 3 dapat diketahui bahwa dalam menilai prestasi belajar guru memperoleh skor 68 yang mana dikatakan belum berhasil karena skor kurang dari $75 \%$ dengan jumlah guru berhasil semua dalam indikator menilai hasil belajar, menyusun laporan, serta memperbaiki soal perangkat penilaian dan dalam indikator mengolah hasil belajar hanya 6 guru yang dapat melaksanakannya. 
Tabel 4. Hasil Melaksanakan Tindak Lanjut Hasil Penilaian Siklus I

\begin{tabular}{llccc}
\hline NO & \multicolumn{1}{c}{ Indikator } & $\begin{array}{c}\text { Jumlah } \\
\text { Guru }\end{array}$ & $\begin{array}{c}\text { Jumlah } \\
\text { Guru } \\
\text { berhasil } \\
\text { (skor>75) }\end{array}$ & $\begin{array}{c}\text { \% } \\
\text { keberhasilan }\end{array}$ \\
\hline 1 & $\begin{array}{l}\text { Menyusun soal perangkat } \\
\text { penilaian }\end{array}$ & 10 & 6 & 60 \\
2 & $\begin{array}{l}\text { Melaksanakan penilaian } \\
3\end{array}$ & 10 & 7 & 70 \\
Memeriksa jawaban/memberi & 10 & 5 & 50 \\
4 & $\begin{array}{l}\text { Mer } \\
5\end{array}$ & 10 & 5 & 50 \\
$\quad \begin{array}{l}\text { Menilai hasil belajar } \\
\quad \text { Jumlah }\end{array}$ & 10 & 4 & 40 \\
\hline
\end{tabular}

Berdasarkan tabel 3 dapat diketahui bahwa dalam melaksanakan tindak lanjut hasil penilaian $54 \%$ yang mana dikatakan belum berhasil karena skor kurang dari $75 \%$ dengan jumlah guru kurang dari 8 orang dapat melaksanakan dari semua indikator yang ada .

Berdasarkan temuan siklus I bagian yang sudah baik dipertahankan, bagi persentase yang keberhasilannya kecil perlu di perbaiki pada siklus II. Perbaikan tersebut yaitu dengan lebih memotivasi para guru, sehingga para guru lebih bersemangat dalam melaksanakan tugasnya. Selain memotivasi supervisor membelikan lebih banyak kesempatan kepada para guru untuk menanyakan hal-hal yang belum jelas. Hasil siklus kedua dapat dilihat pada tabel di bawah ini:

Tabel 5. Hasil melaksanakan Pembelajaran Tindakan Siklus II

\begin{tabular}{|c|c|c|c|c|}
\hline NO & Indikator & $\begin{array}{l}\text { Jumlah } \\
\text { Guru }\end{array}$ & $\begin{array}{l}\text { Jumlah } \\
\text { Guru } \\
\text { berhasil } \\
\text { (skor }>75)\end{array}$ & $\begin{array}{c}\% \\
\text { keberhasilan }\end{array}$ \\
\hline 1 & $\begin{array}{l}\text { Membuka pelajaran dengan metode } \\
\text { yang tepat }\end{array}$ & 10 & 9 & 90 \\
\hline 2 & $\begin{array}{l}\text { Menyajikan materi pelajaran secara } \\
\text { sistematik }\end{array}$ & 10 & 8 & 80 \\
\hline 3 & $\begin{array}{l}\text { Menerapkan metode dan prosedur } \\
\text { pembelajaran yang telah ditentukan }\end{array}$ & 10 & 8 & 80 \\
\hline 4 & Mengatur kegiatan siswa di kelas & 10 & 9 & 90 \\
\hline 5 & Menentukan media pembelajaran & 10 & 8 & 80 \\
\hline 6 & Menggunakan sumber belajar & 10 & 10 & 100 \\
\hline 7 & $\begin{array}{l}\text { Memotivasi siswa dengan cara } \\
\text { positif }\end{array}$ & 10 & 9 & 90 \\
\hline 8 & $\begin{array}{l}\text { Melakukan interaksi dengan siswa } \\
\text { menggunakan Bahasa yang } \\
\text { komunikatif }\end{array}$ & 10 & 9 & 90 \\
\hline 9 & $\begin{array}{l}\text { Memberikan pertanyaan umpan } \\
\text { balik }\end{array}$ & 10 & 8 & 80 \\
\hline 10 & Menyimpulkan pembelajaran & 10 & 10 & 100 \\
\hline
\end{tabular}




\begin{tabular}{ccccc}
\hline NO & Indikator & $\begin{array}{c}\text { Jumlah } \\
\text { Guru }\end{array}$ & $\begin{array}{c}\text { Jumlah } \\
\text { Guru } \\
\text { berhasil } \\
\text { (skor>75) }\end{array}$ & $\begin{array}{c}\text { \% } \\
\text { keberhasilan }\end{array}$ \\
\hline 11 & $\begin{array}{c}\text { Menggunakan waktu secara efektif } \\
\text { Jumlah }\end{array}$ & 10 & 10 & 100 \\
& 10 & 98 & 89 \\
\hline
\end{tabular}

Berdasarkan tabel 5 dapat diketahui bahwa dalam melaksanakan pembelajaran diperoleh skor $89 \%$ yang mana dikatakan berhasil karena skor lebih dari $75 \%$

dengan jumlah diatas 7 orang disetiap indikator yang ada dapat melaksanakannya.

Tabel 6. Hasil Menilai Prestasi Belajar Siklus II

\begin{tabular}{|c|c|c|c|c|}
\hline NO & Indikator & $\begin{array}{c}\text { Jumlah } \\
\text { Guru }\end{array}$ & $\begin{array}{c}\text { Jumlah } \\
\text { Guru } \\
\text { berhasil } \\
\text { (skor }>75)\end{array}$ & $\begin{array}{c}\% \\
\text { keberhasilan }\end{array}$ \\
\hline 1 & Menyusun soal perangkat penilaian & 10 & 9 & 90 \\
\hline 2 & Melaksanakan penilaian & 10 & 10 & 100 \\
\hline 3 & Memeriksa jawaban/memberi skor & 10 & 8 & 80 \\
\hline 4 & Menilai hasil belajar & 10 & 10 & 100 \\
\hline 5 & Mengolah hasil belajar & 10 & 10 & 100 \\
\hline 6 & Menganalisa hasil belajar & 10 & 8 & 80 \\
\hline 7 & Menyimpulkan hasil belajar & 10 & 10 & 100 \\
\hline 8 & Menyusun laporan hasil belajar & 10 & 10 & 100 \\
\hline 9 & $\begin{array}{l}\text { Memperbaiki soal perangkat } \\
\text { penilaian }\end{array}$ & 10 & 10 & 100 \\
\hline \multicolumn{2}{|r|}{ Jumlah } & 10 & 85 & 97 \\
\hline
\end{tabular}

Berdasarkan tabel 6 dapat diketahui bahwa dalam menilai prestasi belajar diperoleh skor $97 \%$ yang mana dikatakan berhasil karena skor lebih dari $75 \%$ dengan jumlah diatas 7 orang disetiap indikator yang ada dapat melaksanakannya.

Hasil penelitian selama dua siklus yang bertujuan untuk meningkatkan kinerja guru terlihat pada siklus pertama dan kedua menunjukan hal-hal sebagai berikut yaitu pada kinerja guru dalam pembelajaran dikelas melalui supervisi edukatif kolaboratif secara periodik ditinjau dari pelaksanakan pembelajaran dan penilai prestasi belajar yang dilakukan guru. Kemudian supervisor mengarahkan dan menjelaskan bagaimana guru memanfaatkan metode supervisi edukatif kolaborasi.

\section{KESIMPULAN}

Berdasarkan hasil penelitian yang dilakukan di SD Negeri Leuwigajah 2 Kota cimahi, dapat disimpulkan bahwa kinerja guru dalam menyusun rencana pembelajaran, melaksanakan pembelajaran, menilai prestasi belajar, dan melaksanakan tindak lanjut penilaian prestasi belajar melalui supervisi edukatif kolaboratif secara periodic dapat meningkat. Dengan adanya pelaksanaan supervisi edukatif kolaboratif secara periodik dapat juga meningkatkan prestasi belajar peserta didik di SD Negeri Leuwigajah 2 Kota Cimahi. Sehingga 
alangkah baiknya bias terlaksana secara terus menerus.

\section{REFERENSI}

Bennett N.B.Silalahi, Manajemen integratif, STIM LPMI, Jakarta, 1999, hl3

Floerence L. Denmark, "Leadership Style", Leadership and Social Change, ed.

William R. Lassey and Marshal Sashkin (USA: University Associates, Inc., 1976),p 74

James H.Donnelly, Jr.,James L.Gibson, and John M.Ivancevich, Fundamentals of Management (Business Publication Inc, 1983), p.405

W. Jack Duncan, Management: Progressive Responsibility in Administration (New York: Random House, Inc, 1983) p.226

Koontz, O'Donnell and Weirich, op. cit., pp.508-509

David Krech, Richad S. Cruthfield and Egerton L. Ballachey, Individual in Society (New York: McGraw-Hill Book Company Inc., 1962),p422

Jane Whitney Gibson an Richards M. Hodgetts, Organizational Communication: A Managerial Perspective (Orlando: Academic Press College Division, 1986), p.16

Paul Pigors \& Charles A.Myers, Personal Administration: A point of View and a Method (Kogakusha, Tokyo: McGraw-Hill Inc, 1977), p422

Suyad prawirisentono, Manajemen Sumber Daya Manusia: Kebijakan Kinerja Karyawan: Kiat Membangun Organisasi Kompetitif Menjelang Perdagangan Bebas Dunia (Yogyakarta: BPFE, 1999), p.31

Andre E. Sikula, Personel Administration and Human Resaurces Management (Santa Barbara: John Willey \& Sons, Inc., 1981),p.402

Henry Clay Lindgren, Educational Pshycology in the classroom (New
York: Oxford University Press., 1980),pp.426-427

Malaya S.P. Hasibuan, Manajemen Sumber Daya Manusia (Jakarta: CV. Haji Masagung, 1994), p.212

Undang, Gunawan, Teknik Penelitian Tindakan Kelas. (Bandung: Sayaga Tama 2012) 